\title{
Analysis of the Human Resource Management Process: A Qualitative Study in the East Halmahera Regency Health Office
}

\author{
Susmito Haruna ${ }^{1 *}$, Muhammad Alwy Arifin ${ }^{1}$, Muhammad Syafar ${ }^{2}$, Darmawansyah ${ }^{2}$, Indar ${ }^{2}$, Anwar \\ Mallongi ${ }^{3}$ \\ ${ }^{\mathrm{T}}$ Department of Health Administration and Policy, Faculty of Public Health, Hasanuddin University, Indonesia \\ ${ }^{2}$ Department of Behavioral Sciences and Health Promotion, Faculty of Public Health, Hasanuddin University, Indonesia \\ ${ }^{3}$ Department of Environmental Health, Faculty of Public Health, Hasanuddin University, Indonesia
}

\section{*Corresponding Author}

Susmito Haruna

\section{Article History}

Received: 13.07 .2020

Accepted: 27.07 .2020

Published: 29.07.2020

\begin{abstract}
HR planning is a systematic process used to predict the demand and supply of HR in the future. The purpose of this research is to analyze the implementation of the human resource management process in terms of the planning, recruitment and selection system at the East Halmahera Regency Health Office. This type of research is qualitative research. Informants in this study are structural officials of the East Halmahera Regency Health Office including 2 district heads, 3 heads, 9 section heads, 2 Community Health Center heads plus 1 structural officer who is competent to provide information regarding research objectives, while the department head has the role as a key informant who is a policymaker at the health service level. The results showed that the planning of health human resources in the East Halmahera Health Service did not meet the requirements both in terms of number, types, and qualifications of education in terms of recruitment of health human resources could not answer the required number, type and qualifications of education based on the analysis of personnel needs and based on health HR Selection in the East Halmahera Health Office it is not implemented properly in the HR management process. Need to improve the process of human resource management in East Halmahera Health Office so that it can meet the requirements both in terms of number, type, and qualifications of education.
\end{abstract}

Keywords: Management, HR planning, recruitment, Selection, Health Office.

\section{INTRODUCTION}

To achieve the success of health development as stipulated in Law Number 36 of 2009 concerning health, a good plan is needed, where the plan can answer existing health problems, to be effective, realistic, and flexible [1]. Health development planning that needs attention is the planning of human resource needs [2, 3]. Achieving the success of an organization is inseparable from the role and availability of quality human resources [4].

Daryanto and Bintoro [5] states that Human Resource Management (HRM) is a science or how to regulate the relationships and roles of resources (labor) which are thought by individuals efficiently and effectively and can be used optimally so as to achieve common goals. In addition, HRM also functions to always monitor the activities and HR needs in the organization so as to create a harmonious atmosphere in the work environment. To develop the HR function, it must be realized that humans are not inanimate objects because humans have feelings.

The competencies of health workers who are identified as the skills, knowledge, and characteristics or behavior required, so that employees can display good performance can also be realized through proper management of HR management. HRM is a strategy that implements Management functions, namely Planning, organizing, leading, and controlling. In every operational activity/function of HR starting from the process of withdrawal, selection, training and development, placement which includes promotion and transfer, performance appraisal, compensation, industrial

Copyright @ 2020: This is an open-access article distributed under the terms of the Creative Commons Attribution license which permits unrestricted use, distribution, and reproduction in any medium for non commercial use (NonCommercial, or CC-BY-NC) provided the original author and source are credited. 
relations, up to termination of employment, which is shown to increase the productive contribution of the organization's HR towards the achievement organizational goals more effectively and efficiently [6].

East Halmahera Regency Health Office by reviewing the Health Office staffing data for the number of employees in 2019 there were 47 people [7]. Since 2003, the division of East Halmahera Regency has been divided. Before the East Halmahera Regency was divided, it was still Tidore of the archipelago so that the population was initially easy to coordinate. But when the government did the division of the Tidore archipelago, which was divided into 3 parts, namely the Tidore Islands, Central Halmahera Regency, and East Halmahera Regency.

When the East Halmahera Regency was divided, it caused a decrease in the number of staff due to the shifting of tasks to the new region division. So that this will certainly disrupt the process of organizing human resource management that has been set by the previous organization. As the results of the author's preliminary study of the implementation of the HR management process in the East Halmahera Regency Health Office, in terms of HR planning, the implementation is in the form of a position formation in the recruitment of employees which is generally determined directly by the Regional Personnel Agency (BKD) even though from the health department has proposed the needs of employees but the decision on the results received are still fully determined by the $\mathrm{BKD}$, in this case, the East Halmahera Regency government. So that the workforce needs in the health department have not been able to meet the needs assessment in the implementation of the program.

Data on the state of health of the East Halmahera Regency Health Office with a total of 401 employees have not been able to answer the provision of services to all people in the work area of the health service as many as 88,844 people which illustrates that the state of health human resource management, especially planning of personnel needs has not met the standards of labor needs based on the number of community targets as a recipient of health services.

Based on this, it is necessary to have more analytical actions in handling the HR Management Process in East Halmahera Regency Health Office. The purpose of this study is to Analyze the implementation of human resource management processes in human terms in terms of the planning, recruitment and selection systems of the Health Department of East Halmahera Regency

\section{METHODS}

This type of research is qualitative research. This research was conducted at the Health Service Office in East Halmahera Regency, North Maluku Province. Informants in this study are structural officials of the East Halmahera Regency Health Office including 2 district heads, 3 head devision, 9 section heads, 2 Community Health Center heads plus 1 structural officer who is competent to provide information regarding research objectives, while the department head has the role as a key informant who is a policymaker at the health service level. Primary data obtained through indepth interviews directly with the informants. The data analysis technique used is the triangulation technique.

\section{RESULTS}

Based on the review of interviews with research informants, HR planning by reviewing aspects of quality and quantity in the East Halmahera Regency Health Office has not been carried out to the fullest. As a result, the available workforce within the scope of the East Halmahera Regency Health Office has not been able to meet the standards.

Furthermore, although human resource planning has been prepared based on the demands of the needs of both the number, type and qualifications of education have been prepared but it is not realized because it is still undergoing changes at the local government level as a policymaker, in this case, the BKD which will also affect the subsequent employment conditions of the scope of the Health Service East Halmahera Regency. follows:

As the results of the interview with structural officials from the East Halmahera Regency Health Office are as

"...I think that the energy is not entirely in accordance with the needs because the number and qualifications of education are not as expected....." (FA, 32 years old)

“....Selama ini pihak Dinas Kesehatan Halmahera Timur sudah merencanakan tetapi semua yang direncanakan itu kembali kepemerintah dalam hal ini BKD, Dinas merencanakan misalnya dibutuhkan dokter sekian, perawat, bidan sekian namun realisasi perencanaan tidak sesuai dengan kebutuhan yang ditetapkan baik jumlah, jenis maupun kualifikasi pendidikan...." (I, 37 years old).

"....There are some doctors that are needed from the General Practitioner, from the dentist including the pharmacist, Health Promotion Likewise with the new expert doctor one person is placed in the hospital while 
the standard is a minimum of 5 expert doctors and also a general practitioner who is highly placed in several health centers, whereas only 6 doctors currently available. (SS, 32 years old).

The same thing found by the Secretary of the East Halmahera Regency Health Office, as follows:

“....Not only specialist doctors, general practitioners have not been available until now about $90 \%$ of all Community Health Center, while only 10\% of general practitioners' needs are met and specialist doctors at the hospital ratio still do not meet the standards...”. (AS, 50 years old).

Based on the analysis of in-depth interview results, it can be concluded that in terms of quality (qualifications and types) and quantity (number) of human resources in the field of health, in this case, personnel, especially those implementing health service providers available for the work area of the East Halmahera Regency Health Office, have not been implemented and have not fulfilled as needed.

These results give an indication that the implementation of HR planning has been carried out and prepared in accordance with needs, but the realization of the plan has not been met according to the requirements set out in the reference plan that has been prepared by the Department of Health previously.

The implementation of the staffing recruitment system at the level of the Health Service seems not to have been carried out in accordance with its designation. This is due to the fact that the revenue system implemented is biased, especially in terms of policy determination.

Recruitment at the East Halmahera Regency Health Service has run well based on needs analysis in accordance with the scientific background and implementation through socialization using letters in each institution but the quota preparation is not according to standards so there are still employees who occupy a position that requires expertise and special scholarship does not match his scientific background. As the results of interviews from several research informants as follows.

"....If the recruitment system I see in the Health Service has been running well because firstly from the personnel administration section has been socializing through letters in each institution about what workers are needed and others....."(FA, 32 years old).

"....The recruitment system is adapted to the scientific discipline, only sometimes it is not appropriate for example the surveillance and immunization sections are sometimes filled in by the Bachelor of Administration and Health Policy $(A K K)$ which should have a Bachelor of Epidemiology....." (I, 37 years old). follows:

The same thing was also stated by the Head of Personnel of the East Halmahera Regency Health Office, as

“....This recruitment has already been selected, namely through a database and general channels.... "(SS, 32 years old) follows:

This was later reinforced by the statement of the Secretary of the East Halmahera Regency Health Office, as

“....The current recruitment system for civil servants is always determined by the BKD. The Health Service is only limited to proposing based on quotas, for example, so for midwives, nurses and other health workers' needs, but the situation of workers is still limited and the Health Service continues to accept it because the center has determined its quota and the amount....." (AS, 50 years old).

Based on the analysis of the results of interviews with research informants, it shows that the recruitment system for recruitment of employees, especially civil servants (PNS) in the health sector, is carried out with the need for rules based on the scientific background needed in a standard requirement that includes the PNS recruitment format. However, in determining the needs stated in the receipt format it is determined directly from the regional government staffing in this case the BKD while structural officials including the Head of Health Office are not involved in the formulation of the format. So that the recruitment system does not seem to be based on an analysis of the need for personnel needed within the scope of the Health Service itself.

The selection system in the world of civil service recruitment, including in the East Halmahera Regency Health Office, tends not to be implemented. This is because prospective employees who will be accepted more have a long enough working period as contract workers who work within the scope of the Department of Health. While the acceptance of contract workers (honorary) proficiency level has fulfilled the path of adjustments to the field of work occupied by the person concerned with appropriate scientific backgrounds. As the results of in-depth interviews with research informants as follows: 
“....In my opinion, it seems that currently the data entered in accordance with needs, for example, we propose to the SKM center, then given SKM so that after they return they are still placed in a vacant place but there are still personnel after being appointed as civil servants in the Health Office environment that is not in accordance with the background. behind her education.... "(FA, 32 years old).

The same thing was also stated by the Secretary of the East Halmahera Regency Health Office, as follows:

"....In the selection process, we only provide information that in these areas, a number of health workers are needed, for example, midwives and nurses, so that once the test and is declared to have passed, there is the only formation based on the first service decree...... "(AS, 50 years old).

Based on a review of information provided by research informants, it can be concluded that the staff selection system in the East Halmahera Regency Health Office is carried out through two channels, namely through the honorary and public channels. In the honorary path for reasons of service, the selection system does not need to be carried out again due to the cost aspect. Whereas the general pathway is still selected and adjusted to the scientific background of prospective employees and needs analysis at the Health Service level

\section{DisCUSSION}

HR planning is a systematic process used to predict demand and supply of HR in the future. In a simple analysis of employee needs is a logical and orderly analysis process to comply with the number and quality of employees needed in an organizational unit [8].

Basically, health human resource planning has been well implemented at the level of the East Halmahera Regency Health Office by answering the analysis of energy needs both in terms of type, number and qualifications of education but the obstacle is the realization of the planning is not in accordance with the requirements that have been determined previously. This is because the planning that was prepared previously by the DHO experienced changes due to the intervention of the local government.

Health HR planning at the East Halmahera Regency Health Office level is carried out with a gradual flow starting from planning at the section level which is then submitted to the subdivision (department) and to the head of the service which is then submitted to the regional staffing department (BKD) as a determinant of staffing policies in the region by involving the regent as the highest policymaker in the region. The results of the planning are in the form of the formation of the number, types, and qualifications of personnel needed.

Research conducted [9] shows that all Community Health Center still lacks promotive and preventive personnel. Likewise with the planning process the Community Health Center does not have special staff or teams as planners in meeting HRH needs. The stages in the HRH planning at the Community Health Center only analyze the HRH needs and then submit it to the Health Office to follow up on the implementation process of the HRH needs. Other research conducted by Purnamasari \& Kapalawi [10] shows the process of human resource planning using the workload calculation method which is carried out annually so that in HR planning there is never a gap in the selection of personnel.

The next step taken in the process of human resource management is to carry out recruitment by offering to the public the existence of a civil service recruitment system, especially at the Health Service level. Recruitment system for recruitment of employees, especially civil servants (PNS) in the health sector in the East Halmahera Regency Health Office is implemented by referring to the need for rules-based on scientific background that is listed in a standard requirement in the formation of Civil Servant reception.

Employee recruitment is a process or action taken by the organization to get additional employees through several stages including the identification and evaluation of sources of labor withdrawal, determining labor needs, the selection process, placement, and orientation of labor [11]. Recruitment at the East Halmahera Regency Health Office level has been carried out effectively, but in determining the quota contained in the recruitment formation is still under the authority of the government both local government in this case the BKD and the central government. This gives an indication that the recruitment system is still influenced by aspects of the local socio-political situation.

The influence of these policies so that the determination of selected employees is not in accordance with predetermined needs standards so that there are health workers who hold a position not in accordance with their scientific fields. This is in line with research conducted by Kelejan et al. [12] demonstrating that effective recruitment requires the availability of accurate and ongoing information about the number and qualifications of individuals needed to carry out various jobs in the organization. 
The next activity carried out in an HR management process is the selection of candidates who are selected as candidates for staff or employees who will be placed in a particular area of responsibility. This selection system must be carried out by reviewing the analysis of employee needs within the scope of the Office of Health. This is to prevent mistakes in choosing the right person. Therefore, the implementation of the selection must consider the "the right man and the right place" aspects, namely, those who will be elected as employees must be adjusted to the vacant position within the scope of the East Halmahera Regency Health Office and in accordance with the needs of personnel based on the planning that was made before

Selection is the next step in the HR management process after going through recruitment channels in the form of determining the personnel selected as prospective employees who will be accepted to work in an organization. Health HR selection in the HR management process at the East Halmahera Regency Health Office was not carried out properly. This is because the admission system that is implemented is still based on honorary staff so that those who are appointed to become civil servants already know and fully understand the organizational condition of the Health Office in terms of organizational structure, rules, and objectives.

In addition, self-selected employees, with the working period that has been served during the service period certainly have qualifications that have been adapted to the conditions of the place of work, and they are appointed to become civil servants as well as in the part of the previous service area. With these considerations also, if the selection carried out will tend to be an obstacle to the effectiveness and efficiency of the HR management process.

Not implementing a selection system in accordance with the standard implementation of the selection in the HR management process does not mean that the selection system does not apply in totality. The selection system applied to civil servants tends to be implemented at the time of admission of honorary employees wherein the recruitment of honorary employees has implemented an HR selection system by reviewing aspects of the needs in the analysis of positions in the Health Service.

The selection system was not implemented specifically through the honorary route because based on the results of the informants' information, employees who had previously been honorary staff were selected based on job analysis and needs analysis before they were placed. So after taking the PNS test those who have passed have been placed back to their previous positions based on the SK contract of the honorary employee. Research conducted [13] explained that the selection process for prospective officials at the Gorontalo City Health Office had not fully met the normative criteria

HR selection at the East Halmahera Regency Health Office will still be carried out if the recruitment system for prospective civil servants is through public channels. This is intended to give an introduction to each officer about the state of the East Halmahera Regency Health Office organization. Statements made by several informants that the determination of the employees elected to work at the East Halmahera Regency Health Office is still in the policy of the regional government in this case the Regent of East Halmahera Regency as the policymaker. Selection is based on needs analysis including job analysis, human resource planning, and recruitment [14].

\section{CONCLUSION}

Based on the results of research and discussion of data collected, this study concludes that health HR planning in East Halmahera Health Service has not met the requirements both in terms of the number, type and qualifications of education in terms of health HR recruitment not being able to answer the requirements for the number, type and qualifications of education that are it is needed based on an analysis of the needs of personnel and based on the selection of health HR in the East Halmahera Health Office not carried out properly in the HR management process. Need to improve the process of human resource management in East Halmahera Health Office so that it can meet the requirements both in terms of number, type, and qualifications of education.

\section{REFERENCES}

1. Yusmardiansah, Y. (2017). Analisis Kebutuhan Sumber Daya Manusia Dinas Kesehatan Kabupaten Kuantan Singingi Tahun 2017. Prepotif: Jurnal Kesehatan Masyarakat, 1(2), 42-53.

2. Standing, H. (2000). Gender: a missing dimension in human resource policy and planning for health reforms. Human Resources Development Journal, 4(1), 27-42.

3. Green, G. (2012). Intersectoral planning for city health development. Journal of Urban Health, 89(2), $247-257$.

4. Sedarmayanti, H. (2018). Manajemen Sumber Daya Manusia; Reformasi Birokrasi Dan Manajemen Pegawai Negeri Sipil, Reflika Aditama.

5. Bintoro, D. (2017). Manajemen penilaian kinerja karyawan. Yogyakarta: Gava Media.

6. Sofyandi, H. (2008). Manajemen Sumber Daya Manusia. Yogyakarta: Graha Ilmu.

7. Profil Dinkes (2018). Profil Dinas Kesehatan Halmahera Timur Tahun 2018. Halmahera Timur: Dinas Kesehatan. 
8. Paruntu, B. R. (2015). Perencanaan Kebutuhan Sumber Daya Manusia Di Community Health Center Kabupaten Minahasa. Jikmu, 5(1), 43-53.

9. Shofiah, R., Prihatini, D., \& Viphindrartin, S. (2019). Perencanaan Sumber Daya Manusia Kesehatan (SDMK) Community Health Center Di Kabupaten Jember. Bisma: Jurnal Bisnis Dan Manajemen, 13(3):181-188.

10. Purnamasari, I., \& Kapalawi, I. (2016). Analisis Proses Manajemen Sumber Daya Manusia Di Rumah Sakit Stella Maris Makassar. Media Kesehatan Masyarakat Indonesia, 9(2), 120-124.

11. Enambe, E. (2015). Analisis Sistem Perencanaan Sumber Daya Manusia Pada Kantor Dinas Kesehatan Kabupaten Tolikara Provinsi Papua. Jikmu, 5(5), 460-468.

12. Kelejan, R. A., Lengkong, V. P., \& Tawas H. N. (2018). Pengaruh Perencanaan Sumber Daya Manusia Dan Pengalaman Kerja Terhadap Kinerja Karyawan Di Pt. Air Manado. Jurnal Emba: Jurnal Riset Ekonomi, Manajemen, Bisnis Dan Akuntansi, 6(4), 1918-1927.

13. Salamate, G. A. (2014). Analisis Perencanaan Sumber Daya Manusia Kesehatan Di Dinas Kesehatan Kabupaten Minahasa Tenggara. Jikmu, 4(4):625-633

14. Pusparani, D. (2018). Analisis Proses Pelaksanaan Rekrutmen, Seleksi, Dan Penempatan Kerja Karyawan (Studi Pada Hotel Dan Restoran Mahkota Plengkung. Jurnal Administrasi Bisnis, 58(2):101-109. 